Musings

\title{
Musings on genome medicine: enzyme-replacement therapy of the lysosomal storage diseases
}

\author{
David G Nathan and Stuart H Orkin
}

Address: Dana-Farber Cancer Institute, 44 Binney Street, Boston, MA 02115, USA.

Correspondence: David G Nathan. Email: david_nathan@dfci.harvard.edu

\begin{abstract}
The lysosomal storage diseases, such as Gaucher's disease, mucopolysaccharidosis I, II and IV, Fabry's disease, and Pompe's disease, are rare inherited disorders whose symptoms result from enzyme deficiency causing lysosomal accumulation. Until effective gene-replacement therapy is developed, expensive, and at best incomplete, enzyme-replacement therapy is the only hope for sufferers of rare lysosomal storage diseases. Preventive strategies involving carrier detection should be a priority toward the successful management of these conditions.
\end{abstract}

The onset of the molecular biology revolution in the 1970s created a tsunami of optimism in biological and clinical circles. Sydney Brenner has described the excitement of basic biologists for whom the new technology offered the opportunity to gather important genetic data in days instead of the weeks or years that were required by the old mating and phenotype technologies [1]. Clinical investigators were equally thrilled with the promise that the new biology might lead to complete correction of genetic diseases for which only partial replacement therapies such as insulin and blood transfusion were then available. We outlined the advent and progress of gene therapy in a previous column [2], in which we emphasized the very slow progress of that field, one that has only recently begun to bear fruit.

Dissatisfied with the frustrations surrounding the medical application of gene-replacement therapies, clinical investigators traveled alternative routes. The first, intact cell therapy utilizing hematopoietic stem cell transplant (HST) was at the start slow to be accepted, but has become standard treatment. The field was made possible by the pioneering work of E Donnell Thomas and his associates, for which Thomas received a Nobel Prize in medicine and physiology. The first applications of HST were devoted to management of acutely fatal hematopoietic malignancies and marrow failure, but as confidence accumulated in the suppression of graft versus host disease, non-malignant hematopoietic diseases became justifiable targets [3-6].
The treatment of Diamond-Blackfan anemia, WiskottAldrich syndrome and thalassemia by HST has been particularly successful. Though the treatment is largely restricted to the $25 \%$ of patients with compatible sibling donors, unrelated histocompatible donors have been increasingly utilized with improving results, and, surprisingly, acceptable results have also been observed with haplo-identical donors [7-11].

Successful gene-replacement treatment has been most frequently reported in the inherited immunodeficiencies [2], but, despite promising murine studies [12-14], there have been no published reports of successful long-term treatment of inherited disorders of myeloid stem cells in humans by gene insertion. Attempts to create corrected stem cells from somatic cells (so-called induced pluripotent stem or IPS cells) have also been effective in murine models of sickle cell anemia in vivo [15] and in human thalassemia in vitro [16]. These approaches, while fascinating, are quite far from clinical trials.

The lysosomal storage diseases (LSDs) are obvious targets of both HST and gene-replacement therapy. Gaucher's disease is an excellent and the most frequent example. It is a disorder in which acid beta glucosidase (glucocerebrosidase)-deficient macrophages loaded with excess glucosylceramide accumulate throughout the reticuloendothelial system and particularly disrupt the functions of the bones, liver, and spleen, and, in some forms, the brain. The disease is inherited as an autosomal recessive trait, and more than 200 various polymorphisms and disease-causing mutations have been reported. Though considerably more frequent among Ashkenazi Jews, the disease is widely distributed. The commonest cause (type 1) is an Asn370Ser point mutation in acid beta glucosidase, but even patients homozygous for this mutation have highly variable phenotypes, presumably due to genetic and epigenetic modifiers. They do not, however, have central nervous system manifestations, presumably because this mutation does not cause complete loss of enzyme activity. In contrast, the

ERT, enzyme replacement therapy; GLA, alpha-galactosidase-A; HST, hematopoietic stem cell transplant; IPS, induced pluripotent stem (cells); LSD, lysosomal storage disease. 
Leu444Pro mutation causes complete loss of enzyme function and is associated with central nervous system disease (types 2 and 3) [17].

HST from a histocompatible sibling donor was first attempted for Gaucher's disease by Rappeport and Ginns in 1984 [18]. While the transplant was technically successful, the very slow removal of glycolipid-loaded macrophages from the damaged organs predicted that the therapy would be frustrating in many cases. Furthermore, despite the results enthusiastically reported more than 15 years later by Krivit and his co-workers [19], it seems unlikely that HST would be a satisfactory approach to central nervous system manifestations of the LSDs. In fact, the few reports in the medical literature suggest that HST is of marginal benefit when used alone in Gaucher's disease [20,21]. Gene therapy approaches have also been far less than spectacular $[22,23]$. The normal glucocerebrosidase gene can be detected after gene transfer and it may be expressed, but, thus far, not to an extent to influence the disease.

Since both HST and gene therapy have not yet fulfilled their promise in Gaucher's disease or other LSDs, enzymereplacement therapy (ERT), despite its incomplete effect and enormous expense, has become the only available stop-gap measure, akin to insulin in diabetes and red cell transfusion in thalassemia.

The LSDs for which ERT is currently the treatment of choice include, in addition to type 1 Gaucher's disease, mucopolysaccharidosis I, II and IV, Fabry's disease, and Pompe's disease [24]. The critical experiments by Elizabeth Neufeld and her colleagues set the stage for that therapeutic development by demonstrating the essential role of cellular mannose receptors in the transport of the relevant enzymes bearing dephosphorylated mannose across the cell and lysosomal membrane [25]. Armed with that knowledge and the ability first to purify the relevant enzyme from human placenta [17], and subsequently to create large amounts of dephosphorylated mannose-bearing enzyme with recombinant methods, the treatment of type 1 Gaucher's disease with ERT became a reality [17].

From the outset of the ERT era, clinical data showed that the bone, hepatic and splenic manifestations of type 1 Gaucher's disease could be improved, but the annual cost of at least \$350,000 per year represents an enormous challenge to any healthcare budget and can only be intelligently supported in a highly productive and efficient health system. In the rare types of Gaucher's disease that affect the central nervous system, there is little or no evidence of benefit from ERT $[24,26]$. ERT to improve the non-neurologically impaired patient's status, followed by HST to achieve sufficiently permanent correction, may be the most useful approach and one that would possibly provide enough enzyme to obviate the continuous and prohibitively expensive use of ERT in this, the most common LSD.

The seven different types of mucopolysaccharidoses are very rare diseases caused by autosomal recessive mutations in various lysosomal enzymes involved in the breakdown of mucopolysacccharides. Type I mucopolysaccharidosis is caused by deficient lysosomal breakdown of glycosaminoglycans and the consequent accumulation of heparan sulfate and dermatan sulfate throughout the body. The disorder is caused by mutations in alpha-L-iduronidase, but the various mutations in the enzyme and unknown modifiers cause three different phenotypes, known, in descending order of severity, as Hurler's, Hurler-Scheie and Scheie's syndromes. Cardiopulmonary, neurologic and multiple organ involvements are characteristic, but the pace of the disorder varies as noted above. Hence ERT can delay the onset of symptoms, and patients genetically destined for a shorter course may live into mid-life [27], albeit at gigantic cost.

Fabry's disease is an X-linked disorder caused by mutations in alpha-galactosidase-A (GLA) that lead to the accumulation of neutral glycosphingolipids, particularly globotriaosylceramid and galactosylceramid, both of which accumulate in the cornea and vasculature and cause renal and cardiac failure as well as neurological damage. Hundreds of mutations in GLA have been described, and the pace of the disease in affected males is related to the degree to which GLA synthesis is impaired. In fact Fabry's disease should be considered in otherwise normal males with unexpected onset of renal or cardiac failure. Benefits of treatment with ERT can be demonstrated in clinical trials but it may be difficult to measure clinical benefit in an individual patient because the pace of the disease is quite slow [28].

Pompe's disease is an autosomal recessive disorder caused by mutations in acid alpha-glucosidase. This leads to accumulation of glycogen in lysosomes, particularly in muscle, and produces weakness and respiratory and cardiac failure that may appear at any age, depending upon the severity of the mutations. The disease is usually slowly progressive. ERT is approved for Pompe's disease but transport of the enzyme across muscle requires a high concentration of the product and the response to treatment is usually quite slow [29].

Clearly ERT is at best an incomplete and tremendously expensive treatment that is most effective when applied in classic non-neuropathic Gaucher's disease. But it does represent a hopeful development for sufferers of the rarer LSDs and may save lives until more effective genereplacement therapy can take its place in our treatment portfolio. It seems likely, however, that the LSDs can be prevented by implantation genetic technology if carriers 
are identified prior to procreation. The focus of our efforts in the management of these diseases should surely be directed toward prevention.

\section{Acknowledgments}

The authors are grateful to Drs Mark Goldberg and John Yoo of Genzyme Corporation for their assistance.

\section{References}

1. Brenner S: My Life in Science. London: BioMed Central; 2001.

2. Nathan DG, Orkin SH: Musings on genome medicine: gene therapy. Genome Med 2009, 1:38.

3. Johnson FL, Thomas ED: Treatment of relapsed acute lymphoblastic leukemia in childhood. N Engl J Med 1984, 310: 263.

4. Camitta BM, Storb R, Thomas ED: Aplastic anemia (first of two parts): pathogenesis, diagnosis, treatment, and prognosis. N Engl J Med 1982, 306:645-652.

5. Camitta BM, Storb R, Thomas ED: Aplastic anemia (second of two parts): pathogenesis, diagnosis, treatment, and prognosis. N Engl J Med 1982, 306:712-718.

6. Thomas ED: Marrow transplantation for nonmalignant disorders. N Engl J Med 1985, 312:46-48.

7. Myers KC, Davies SM: Hematopoietic stem cell transplantation for bone marrow failure syndromes in children. Biol Blood Marrow Transplant 2009, 15:279-292.

8. Alter BP: Bone marrow transplant in Diamond-Blackfan anemia. Bone Marrow Transplant 1998, 21:965-966.

9. Filipovich A: Hematopoietic cell transplantation for correction of primary immunodeficiencies. Bone Marrow Transplant 2008, 42 Suppl 1:S49-S52.

10. Kapoor N, Crooks G, Kohn DB, Parkman R: Hematopoietic stem cell transplantation for primary lymphoid immunodeficiencies. Semin Hematol 1998, 35:346-353.

11. Lucarelli G, Gaziev J: Advances in the allogeneic transplantation for thalassemia. Blood Rev 2008, 22:53-63.

12. Lisowski L, Sadelain M: Current status of globin gene therapy for the treatment of beta-thalassaemia. $\mathrm{Br} \mathrm{J}$ Haematol 2008, 141:335-345.

13. Imren S, Payen E, Westerman KA, Pawliuk R, Fabry ME, Eaves CJ, Cavilla B, Wadsworth LD, Beuzard Y, Bouhassira EE, Russell R, London IM, Nagel RL, Leboulch P, Humphries RK: Permanent and panerythroid correction of murine beta thalassemia by multiple lentiviral integration in hematopoietic stem cells. Proc Natl Acad Sci U S A 2002, 99:1438014385.

14. Pawliuk R, Westerman KA, Fabry ME, Payen E, Tighe R, Bouhassira EE, Acharya SA, Ellis J, London IM, Eaves CJ, Humphries RK, Beuzard Y, Nagel RL, Leboulch P: Correction of sickle cell disease in transgenic mouse models by gene therapy. Science 2001, 294:2368-2371.

15. Hanna J, Wernig M, Markoulaki S, Sun CW, Meissner A, Cassady JP, Beard C, Brambrink T, Wu LC, Townes TM, Jaenisch R: Treatment of sickle cell anemia mouse model with iPS cells generated from autologous skin. Science 2007, 318:1920-1923.

16. Ye L, Chang JC, Lin C, Sun X, Yu J, Kan YW: Induced pluripotent stem cells offer new approach to therapy in thalassemia and sickle cell anemia and option in prenatal diagnosis in genetic diseases. Proc Natl Acad Sci U S A 2009, 106:9826-9830.

17. Barton NW, Brady RO, Dambrosia JM, Di Bisceglie AM, Doppelt SH, Hill SC, Mankin HJ, Murray GJ, Parker RI, Argoff $C E$, et al.: Replacement therapy for inherited enzyme deficiency - macrophage-targeted glucocerebrosidase for Gaucher's disease. N Engl J Med 1991, 324:1464-1470.

18. Rappeport JM, Ginns El: Bone-marrow transplantation in severe Gaucher's disease. N Engl J Med 1984, 311:84-88.

19. Krivit W, Peters C, Shapiro EG: Bone marrow transplantation as effective treatment of central nervous system disease in globoid cell leukodystrophy, metachromatic leukodystrophy, adrenoleukodystrophy, mannosidosis, fucosidosis, aspartylglucosaminuria, Hurler, Maroteaux-Lamy, and Sly syndromes, and Gaucher disease type III. Curr Opin Neurol 1999, 12:167-176.

20. Hoogerbrugge $P M$, Brouwer $O F$, Bordigoni $P$, Ringden $O$, Kapaun P, Ortega JJ, O'Meara A, Cornu G, Souillet G, Frappaz $D$, Blanche S, Fischer A, Ringden O: Allogeneic bone marrow transplantation for lysosomal storage diseases. The European Group for Bone Marrow Transplantation. Lancet 1995 , 345:1398-1402.

21. Tsai P, Lipton JM, Sahdev I, Najfeld V, Rankin LR, Slyper AH, Ludman M, Grabowski GA: Allogenic bone marrow transplantation in severe Gaucher disease. Pediatr Res 1992, 31: 503-507.

22. Weinthal J, Nolta JA, Yu XJ, Lilley J, Uribe L, Kohn DB: Expression of human glucocerebrosidase following retroviral vector-mediated transduction of murine hematopoietic stem cells. Bone Marrow Transplant 1991, 8:403-412.

23. Schiffmann R, Medin JA, Ward JM, Stahl S, Cottler-Fox M, Karlsson S: Transfer of the human glucocerebrosidase gene into hematopoietic stem cells of nonablated recipients: successful engraftment and long-term expression of the transgene. Blood 1995, 86:1218-1227.

24. Rohrbach M, Clarke JT: Treatment of lysosomal storage disorders: progress with enzyme replacement therapy. Drugs 2007, 67:2697-2716.

25. Neufeld EF: The uptake of enzymes into lysosomes: an overview. Birth Defects Orig Artic Ser 1980, 16:77-84.

26. Weinreb NJ: Imiglucerase and its use for the treatment of Gaucher's disease. Expert Opin Pharmacother 2008, 9:19872000.

27. Clarke LA, Wraith JE, Beck M, Kolodny EH, Pastores GM, Muenzer J, Rapoport DM, Berger KI, Sidman M, Kakkis ED, Cox GF: Long-term efficacy and safety of laronidase in the treatment of mucopolysaccharidosis I. Pediatrics 2009, 123:229240.

28. Zarate YA, Hopkin RJ: Fabry's disease. Lancet 2008, 372: $1427-1435$.

29. van der Ploeg AT, Reuser AJ: Pompe's disease. Lancet 2008, 372:1342-1353.

Published: 9 December 2009

doi:10.1186/gm114

(c) 2009 BioMed Central Ltd 